\title{
Entangled Emplacement: Ethnographic Reading of Canadian Muslims' Engagement with the World of Palliative Care
}

\author{
Parin Dossa \\ Professor of Anthropology \\ Simon Fraser University
}

Abstract

\begin{abstract}
How do Canadian Muslims engage with the exclusive and ambiguous terrain of palliative care? An ethnographic response to this question requires addressing a systemic paradox, namely, patient-centered and compassionate care is contingent upon diagnoses of terminal illness. Drawing upon long-standing research among Muslims in metropolis Vancouver, this study uses the construct of entangled emplacement to show the multiple ways in which research participants engage with this paradox. Allied closely to the unconventional ethnographic methods of mindful walking, memory work, and imagining home, the construct of entangled emplacement captures the research participants' expansive understanding of palliative care; this includes the process of displacement and reimagining a diasporic "home", tangled elements of which come into play at the time of death. In the light of neoliberal restructuring of the Canadian health system, I explore the implications of research findings for deep-level conversations across socio-cultural and medicalized boundaries, and tangled pathways of what has come to be known as "palliative care".
\end{abstract}

Keywords: emplacement, palliative care, Canadian Muslims, displacement, reimagining a diasporic home, deep-level conversations

A discussion on the subject of palliative care must begin with the paradox that is rarely spelled out, namely, palliative care is only accessible to those diagnosed with terminal illness. How is it that compassionate and patient- 
centered care is only provided to those diagnosed with terminal illness? It is important to explore this question from two vantage points: First, palliative care is a system that came about to remedy the shortcomings of allopathic medicine (Dilworth-Anderson et al., Frey et al. 2013, Williams et al. 2010). Premised on the reductionist model of mind-body split, the medical model deploys the language of measurement and scientific abstractions, overlooking subjective realities (Lock \& Nguyen, 2010). A diagnosis of terminal illness allows patient-centered palliative care to enter the picture. In the words of the interlocutors, "We tell the patients, 'we will hold your hand all the way through." And "We will walk the journey with you." Yet, palliative care has not been able to free itself from its parent allopathic model. It is the physician's diagnosis which determine if a patient is palliative and this also is delimited to a period of six months or less. Second, management of pain is an important consideration in palliative care with its philosophy of dignified death. Once again it is the allopathic physician who prescribes and monitors the medication. Also, there is a budget allocation: in Canada, the state pays for the physicians and one or two registered nurses (RNs). The hospice takes care of housekeeping as well as emotional support. It is no wonder that hospices recruit a sizable number of volunteers and engage vigorously in fundraising activities.

Given this scenario, my goal in this paper is to explore how two Canadian Muslim minorities (Iranians and Ismailis) respond to the paradox embedded in palliative care. My long-standing research with these two communities in metropolitan Vancouver drew me to explore participants' concerns about palliative care. I am interested in seeing how these groups negotiate a system that has not included them structurally (Anderson \& Kirkham, 1998). This paper is thus organized as follows: I first present a brief profile of the two communities that formed part of my ethnographic research in metropolitan Vancouver over two decades. I then discuss the theoretical framework and the methodology I deployed in my research that included palliative care professionals (physicians, nurses, and frontline workers). Second, using the theoretical construct of emplacement, I analyze the data in relation to interconnected themes of mindful walking, memory work, and reimagining home. These themes, I argue, create space for the participants to tell their own stories. I take the position that the words, voices, and life experiences of racialized minorities must enter into the professional space of palliative care providers if we are to work toward a more humane and just form of care. It is for the purpose of deep-level conversations between care recipients and professionals that I explore the potential of engaged anthropology in the conclusion. 


\section{"We are the children of the Revolution": A Community of Canadians of Iranian Origin}

The Iranian Revolution (1978-1979) is the singular event that defines the settlement of the community in Canada and other parts of the western world. The revolution's inception is the landmark period when waves of Iranians left the county to escape persecution, mandatory drafting of their children, and disappointment in the objectives of the revolution (democracy and freedom from oppressive rule) not being realized. Displacement translates into loss of network of relationships and familiar environment, and in some cases, dispersal of families. This social loss is never recuperated but it may be reconfigured given an amicable environment. This aspect is not given priority in host countries and hence immigrants take it upon themselves to rebuild their social environment. Such is the case with the Iranians; upon their arrival to metropolitan Vancouver, they established a hub in the North Vancouver region. I learned that they were drawn to this part as the mountains reminded them of Tehran (the capital city of Iran). Settlement of a few families attracted others until a sizable community came into being. Lonsdale, the main street in the North Shore, became the nascent home as families rented apartments and ventured into the commercial sector, setting up stores and commercial service centers (lawyers, insurance agents, doctors, and realtors among others). Walking on Lonsdale and other streets in the vicinity, as I did many times, you would certainly come across Canadians of Iranian origin shopping, socializing, and enjoying a "homeland" ambience, a point covered by Mankekar in her work on Indian stores in the San Francisco Bay Area. She notes that grocery stores provide "a crucial node in the transnational circulation of texts, images, and commodities" (2002).

In this world of global capitalism, migration is viewed in economic terms. A person's worth is measured in relation to his or her economic contribution. Immigrants are often left to their own resources to work their way up into the echelons of the labor force. This opportunity is not given to older persons as ageism along with race, gender, and ethnicity works against their efforts to move forward. When it comes to older persons, one needs to be attentive to their experiential knowledge acquired over a lifetime in multiple contexts and historical circumstances. It is for this reason that I decided to focus on aging Canadians of Iranian origin as well as aging Canadian Ismailis. My earlier research with these communities revealed that it would be morally inappropriate to dismiss this constituency under the banner of a dependent service population to which the state has relegated them. Embodying history, culture, and or religious traditions, these individual have much to say about health, illness, and healing as well as dying, death, and what it is like to be a recipient of palliative care. 


\section{Defining Moment: The Ugandan Exodus}

A population of Canadian Ismaili Muslims were also compelled to leave their home countries of Uganda, Kenya, and Tanzania in the post-independence period of the 1970s and 1980s. The triggering factor was the expulsion of South Asians (Muslims, Sikhs, Christians, Parsees, and Hindus) from Uganda. Its former dictator, Idi Amin (1925-2003), used the Asians as a political ploy to bolster his oppressive regime. Asians had lived in Uganda, as in the other two countries, for three generations. Guided by their spiritual leader known as the $49^{\text {th }}$ Imam (the Aga Khan), a descendent of Prophet Muhammad, the Ismailis had taken up citizenship in all three countries. The eviction of the Ugandan Asians in 1972 prompted Ismailis from Kenya and Tanzania to migrate as well largely to western countries such as Canada, United States, and England.

Jamat Khana (mosque) constitutes the religious mainstay of the life of this Ismaili community. Here, prayers and ritual ceremonies are performed every day, early in the mornings and in the evenings. Considered to be vital for the growth and development of the community, Ismailis by and large live near Jamat Khanas - more than ten in British Columbia. A purpose-built Jamat Khana in Burnaby was completed in 1985 at which time the Aga Khan said,

The Ismaili community has sought to create a building here which is both Islamic in its architectural inspiration and of a quality to enhance the overall distinction of Burnaby. The Jamat Khana is designed to be a social and cultural center, as well as a place of congregation. It expresses the Ismailis' desire to give of their best to the cultural and economic fabric of Canada. They are proud that it symbolizes their commitment both to this country's future and their ancient heritage. Nor is there any dichotomy in this dual aim. Muslims believe their faith is not for one time, but for all times and so there cannot be conflict between tradition and modernity (www.Isamili. org)

Members of the Canadian Ismaili community report having done well in economic terms and continued striving to bridge the dichotomies noted above. But this discursive articulation of the community's orientation has yet to include marginalized constituencies such as persons with disabilities and older persons. The latter are relegated to the margins by the state; families are also implicated as their busy lives in the economic sector leaves minimal time for them to spend with older kin. I have therefore paid special attention to aging Canadian Ismailis (and Canadians of Iranian origin) to highlight their invaluable contributions, encapsulated in the final stage of life. 


\section{Listening to the Voices of the Disenfranchised}

My ethnographic research on both of these communities revealed that the topic of dying and death formed part of regular conversation. Anchored in cherished traditions, the following examples - shadows of a vast body of literature - are noteworthy. Jalaluddin Rumi, a household poet for the Canadians of Iranian origin, has this to say about life and death: "You were born with wings, why do you prefer to crawl through life"; and "[d]on't grieve anything you lose. It will come around in another form." For South Asian Ismailis, the Ginans (melodious meditative knowledge) are a rich source of insights on existential issues. Composed in the $11^{\text {th }}$ and $12^{\text {th }}$ centuries by the Pirs (wise men), they are recited every day in the Jamat Khana and also informally in the homes. Here are two examples: "On the day of my death, call me and keep me close to you [the divine being] and hold my hand;" and "live in a good way, you are definitely going to die." These traditions are contextually internalized by people who recite them day in and day out. The body of knowledge from both of this study's communities - they are not merely textual - require an expanded and context-based understanding of life and death. It is for this purpose that I use the theoretical framework of entangled emplacement.

Evoking social space and temporal realities, entangled emplacement brings to light the multiple ways in which people engage with as life circumstances unfold across socio-cultural and politicized boundaries (Dyck 2006; Gedalof 2007, 2009). In this study, this construct enables me to capture study participants' trajectories of migration and resettlement over the course of their lives. I use the term entanglement to reveal the workings of structural factors unfolding locally, in the context of heath, illness, and the end of life. Methodologically, the framework of emplaced engagement may be understood in relation to three interconnected themes: mindful walking, memory work, and reimagining home. These themes are more fully explained later in this article..

Contacts were established through community organizations, especially British Columbia Hospice Palliative Care Association (my collaborator), advertisements in community newsletters and attendance at relevant community gatherings. I also recruited participants from my long-standing research with these communities. My research assistants, indigenous and mainstream, assisted in recruiting other participants. Ethnographic study is nuanced; it does not lend itself to numbers except for formal interviews. At the time of the writing of this paper, we talked to 25 family members of which five were recipients of palliative care). The majority of the formal interviews were digitally recorded and transcribed. Interviews with participant families were conducted in the indigenous languages of Farsi and Gujarati. 


\section{Mindful Walking}

Adopted from art education and museum studies professor Yuha Jung's work (2014), I engaged in mindful walking to explore the surrounds of three hospices I visited the most in Burnaby and Coquitlam. These are the sites where I met several families and their loved ones. To maintain the confidentiality of these premises, I provide a general rather than specific accounts.

The starting point for mindful walking is the physical structure of the premises. I found it interesting that the hospices blended architecturally with the environment. They did not stand out as distinct units until one read the sign. While the latter indicated that the place was for terminally ill persons, it inadvertently kept out other people residing in the area. The people by passed the hospice. This has to do with the fact that as a society we do not accept the existential reality of growing old and dying (Lamb 2014). If you were to enter the hospice, you would find it inviting and warm indicated by the décor (warm colors), comfortable sofas, flowers and plants, and nature-based photographs. Likewise, the residents' rooms have several amenities such as pictures, televisions, phones, and a sofa for families to sit on while visiting. Some of the rooms have extra beds for families to stay the night. In short, every attempt is made to ensure that the residents and their families are comfortable. While the resident is the occupant of a room, measures are taken to ensure his or her privacy.

Allied to the lived realities of everyday life, mindful walking brings to light other dimensions primary among which is the hierarchical division of labor within the professional sector. The physician attends to the medical care of the patient, monitoring his or her progress in consultation with the family. The nurses constitute the second layer ensuring that the physician's directives are followed. The frontline workers take care of personal hygiene along with what has come to be known as the "bed and body work". The volunteers, present in sizable numbers in two- or three-hour shifts, focus on the work of affect; this include talking and listening to patients, and in the words of volunteer Rozy, "holding their hands and just being there for them." This does not mean that the work of affect is not carried out by other professionals. The issue is that the latter are busy and understaffed; hence they have little time for this work. Family-provided care fills in the gaps, as the families that I came to know indicated that they carried the burden of care work.

Mindful walking drew my attention to the activities carried out at the hospices. The usual activities included crafts, knitting, and music. Patients and families participated as and when they desired. The frontline workers reported that immigrants did not participate fully in the activities. Different workers had different opinions on the lack of participation: (a) "Well, there are very few minorities in hospice. I think they are not able to fit in" (Susan); (b) "They are grateful to be in hospice. They say that they do not want to bother us as some of 
them have to be wheeled into the main hall" (Karen); (c) "Many of them do not speak English. How can they participate? We try and have translators when we can" (Katherine); (d) "They do not participate as they have not integrated into the Canadian way of life" (Amanda).

These responses suggest the workings of structural factors identified in critical scholarship such as inaccessibility to health care and a Eurocentric health system embedded in structural racism. Overlooked is the history of colonization and continual imperialism - a theme that I will visit later. My conversations with the interlocutors' suggest that the issue does not rest merely at the level of activities but contain the larger script of resettlement in a new country. I bring to light the layered contexts in relations to other themes.

Outside the premises of a hospice, mindful walking revealed the absence of community/communities. My observations reveal that people on the street were disinterested. It appeared like a place out of this world that people did not want to know or converse about. It was a building that they passed by quickly. The only time it attracted attention was when there was a fundraising fair or bake sale in the lounge. I had an opportunity to attend two of these fairs. Noticeably absent were the residents and their stories. The lounge where the fair was held was rendered into a neutral space. Talk on dying and death was not articulated even in the form of art, paintings, or poetry.

Mindful walking then alerts us to become aware of what is absent and draws out attention to spaces that can be used to foster social relationships and conversations on existential issues such as life and death, the mainstay of human life. The park is a salient aspect of hospice. It is a feature that is advertised and brought to the attention of potential residents and their families. My understanding of the park (natural or landscaped) is that it is a place where people come together for recreation, picnics, and socialization. The parks attached to the hospices were different. By and large, there did not seem to be a presence of people unaffiliated with the hospice in them. It seemed to be silently conveying the message that people who come here (accompanied by families or caregivers) are nearing death. Yet bodies are not passive. There is such a thing as body language provided we pay attention to it. People who sit on the benches or are wheeled in chairs convey the message, not of death but also of lived life, embedded in memories and stories; for immigrants these include trajectories of displacement, migration, and resettlement, as noted below.

Mindful walking draws our attention to potentialities - what could have been. The more I walked around my designated sites, the more I realized how "isolated" and cut off the hospice facilities were -- not physically, but socially and symbolically. There were not connected to communities - a critique applicable to other facilities as well - and neither did members of the community visit them, except for volunteers, therapists, and invited others. I consider mindful walking to be of value as it draws our attention to absences and potentialities. 


\section{Memory Work}

The importance of memory work has been brought to light by anthropologists and practitioners of other disciplines. First and foremost, memory work creates space for participants to remember in their own terms - of significance for people subject to the trauma of displacement and resettlement, as was the case with my participants. When people remember critical events, they speak as a cohort that is in a testimonial voice. It is at this level that their voice carries greater force notwithstanding the importance of singular narratives. In the act of remembering, the participants seek to engage a wider audience of stakeholders and social actors. The point that needs emphasis is that when people tell their stories or storied vignettes (critical component of memory work), they do not do so for the sake of remembering. Their act of telling is politicized where the past is rendered present and the present is conceived as part of the future, if not for themselves then for posterity. Memory work assumes greater significance in palliation; at issue is the foundational narrative of humankind. Memories may be enacted where words cannot fully capture one's experiences. These examples came from the two study communities: I would like to note that I did not set out to study women, the gendered nature of care work limited the number of potential male participants.

\section{Shabina: Making a case for social palliation}

Shabina approached us (my research assistant and I) through an advertisement we had placed in a Farsi newspaper. She wished to share the story of her 45 -year-old son, Ali; she is 76 years old. Seated on a sofa along with Ali she enacted a critical event that happened many years ago in Iran. Using her hands, she explained how her son Ali fell from the bed when he was a baby. He did not cry but developed severe migraines that he has experienced all his life. He had a CT scan in Iran as well as in Canada. Described as having the IQ of a fifteenyear-old, she has received the diagnosis that Ali will never be cured. She stated that he is lovable, polite, and very giving, and she is sad that "[h]e has missed out on all the joys of life; success from schooling, a satisfying job, marriage, and children." Putting her hand on the head, she continued, "If he has a migraine on a particular day, he will not be able to leave his room. He has to remain in the dark until the pain becomes less. During the pain, he gets frustrated." She then explained how difficult it is for her (a widow) and her other two children to take care him. "Both my son and daughter have dedicated their time and money to help him. Both of them are missing out from living their own lives. I am so tired mentally and physically."

Referring to our study on palliative care, she said, "I feel that my son is undergoing palliative care. There is no cure for his disease. Instead we give him medication and opportunities for social interaction to improve his quality of 
life. I believe care without hope for cure or improvement of the illness should fall under palliative care. We wish to make his life as easy as we possibly can giving him medicine and family support so he can live the way he pleases. I think this type of care should be patient-focused and should consistently take into consideration their wants and needs. To consent to what they want to do is giving them some control of their uncontrollable life." Toward the end of our interview, Shabina speaks in a testimonial voice rendering her narrative more powerful. She is advocating a broader baseline for palliative care. Shabina was able to bring Ali to Canada only because she took on the responsibility of taking care of all his needs for a period of ten years. This responsibility has brought about greater stress for her.

I have placed her enactment of her story under memory work because of how she relates it. Shabina has made a choice not to foreground "remember" her own life situation of how she became a widow or the fact that she is aging; neither does she talk about the lives of her other children except to state how the whole family is involved in taking care of Ali. This case of family-centered care raises a critical question: Should not the family-centered premise of palliative care be reexamined? Does this focus not echo the biomedical orientation of self-responsibility and self-care brought about by the restructuring of the health system? More importantly, Shabina's memory work - construction of a life course event linking Iran and Canada through the body of her son - suggests that palliative care cannot be confined to the discrete space of the hospice.

\section{Rubina: Remembering a loved one}

Rubina, originally from Kenya, gave the following account in the way of remembering her husband, Navroz:

One day in Jamat Khana, my grandson saw an older person stagger. To him, that man did not look well. He quickly found his father [Rubina's son] and told him there was a man who did not look well. "Come quickly," he told his father. So my son and grandson rushed to that person and asked him how he was feeling. Realizing that he was critical, they called a First Aid Ismaili volunteer who called for an ambulance and the man was rushed to the hospital. Three weeks later, this person passed away.

Rubina proudly recalled how her grandson had learnt compassion by seeing what Navroz went through. She commented, "It is amazing how this young child absorbed such compassion by observing what was happening to his sick grandfather." Remembering her husband through her grandson was significant. It meant that his life did not come to an end upon death. It became part of posterity to be recalled and remembered in particular contexts.

Rubina's memory work included what is referred to as the immigrant story: 
the struggle to settle down in a new place following displacement. Referring to her husband, she stated, "[h] e found it difficult to settle down. He was unhappy and depressed. He missed his Kenyan lifestyle. He missed his circle of friends. He wanted to return to Kenya. Life in Canada did not give him the satisfaction. He wanted to go back but his children were well-settled and he did not want to uproot them." According to Rubina, he carried a lot of "emotional baggage." Mental stress along with his own lifestyle (he smoked and had high blood pressure) led to a series of strokes that left him paralyzed; accurate medical diagnoses also lagged behind as he was sent home several times from the hospital with the message that he was all right.

As Navroz's condition became worse, family members stepped in to take care of him. Rubina remained the primary caregiver; his sister and his son assisted. At one point, during a heart surgery, he went into coma. The cardiologist recommended that he be taken off life support. His son refused stating, "Only God knows." Rubina had satado performed for Navroz. Satado is an Ismaili ritual whereby the whole congregation offers prayers in the Jamat Khana for the afflicted person over a period of seven days. "Nothing happened for six days. On the seventh day, my husband became conscious." He was then placed in a palliative room in the hospital. The circle of family members taking care of Navroz widened. His sisters and Rubina's sisters took turns to visit him. Meanwhile a physiotherapist and a speech therapists helped him to recover. Rubina observed that his recovery was also facilitated by the fact that his daughter put family pictures on the wall and brought some tapes containing ginans and his favorite songs "so that he could hear them through a headset." Navroz went home and was fine for a while. He even took a trip with his son to his homeland in Kenya.

Upon his return, he had another massive stroke. This time he was cared from home. Rubina had taken up a job with an advertisement firm. She hired a young Filipino woman [Delya] to take care of him. His physical and speech therapy continued. He gained his speech and Rubina attributed this to one more factor. The Filipino woman had a young child who would sit on his lap and ask him to read her a story. Rubina noted, "His speech got better. We could not tell any difference from before."

Rubina was under a lot of stress. In her words, "Worrying about Navroz, sleepless nights, worrying about the children, emotional and physical stress, exhaustion physical and mental, lots of body aches and pains." She had resilience: She held the family together, attended Jamat Khana early in the morning (4:00 a.m.), went for walks, and practiced yoga. Eventually, she gave up her work and stayed at home. Equally healing was to see her grandson "learn about compassionate care that the family provided to my husband."

As Navroz's condition got worse, he was admitted to a nursing home and not a hospice as the family had requested. Realizing that the condition at the 
nursing home was not ideal, the family took on the responsibility of caring for him. They showered him, took him for walks, prepared his meals and fed him. He collapsed again. Navroz was then given a palliative room in the hospital. After a few days, he ordered chai and cookies for the whole family. "It was a good day. He did not appear to be in any pain or discomfort. This was Saturday. On Monday morning he never woke up." Rubina noted that herself and her family were exhausted and were subject to a lot of emotional stress as they moved in and out of the hospital, nursing home, and palliative care.

Through memory work five years after Navroz's death, Rubina reconfigures the meaning of patient- and family-focused model of care. For her, this form of care includes the element of faith. The holistic form of care the family exercised came into play not through a recipe like formula but through circumstances as they evolved with Navroz's illness trajectory. It appears that Navroz fell in between the cracks as far as the system went. It was his family who held his hand to use the palliative care metaphor to ensure that his dignity was maintained through the intertwined elements of faith and medicine, organic healing, and medical therapies. Rubina's remembering of Navroz's life also suggests and expanded model of care one where medical diagnoses and faith are intertwined with alternative forms of healing. How these could be integrated into family-centered palliative care is the question that Rubina's remembering of a life suggests. Ironically these alternative (non-medicalized) forms of care came to light only because the family was compelled to care for Navroz, physically, emotionally, and socially.

\section{Reimagining Home}

How does one reimagine a home in this age of migration, mobility, and diaspora? We may be tempted to adopt a flexible and more complicated understanding of this phenomenon, keeping in mind that home has never been a fixed entity throughout the course of the history of humanity. The notion of home simultaneously suggests stability and an anchorage especially in times of turmoil (Erel 2009, 2011; Gedalof 2007, Gilmartin \& Migge 2015). Objects present in a home embody history and cultural traditions, as well as modern-day consumerism. There are multiple entry points through which we can acquire an understanding of what home is for individuals connected to kin, community/ communities, and increasingly a transnational terrain. Two questions guided my understanding of home: How do interlocutors reimagine home given the ambivalent dynamic of fluidity and stability? How do care recipients conceive of "home" in palliative care given its commitment to create a home-like ambience? Below I present a micro-level analysis of a home as it comes to light through the lens of embroidery work found in participant homes and the space of Jamat Khana. 


\section{Embroidery Work: Noor: "Embroidery reminds me of my life history."}

I was born in the village of Masouleh [in Iran]. I only studied until grade 6. There were no schools after this grade in my village. My father said, "You must have some useful skill." He asked my aunt to teach me how to do embroidery/needle work. I learned different patterns for cushion coverings, table clothes, dresses, wall hangings, and so many other things. When I got married at the age of sixteen, I moved to Shiraz. My husband had a large family. My in-laws liked that I was good at embroidery work. When the prices started going up, my in-laws made me do embroidery work for sale. I was not happy as I had to work for ten hours a day. My eyes would water. Only when factory-made embroidery became popular could I slow down. Machine-stitched embroidered work is cheaper. After the Revolution we had to move to Canada. My son worked for the Shah. It was not safe for us to stay there. Over the years, I had collected all kinds of embroidered pieces. I could bring some. I left other pieces with my sister in Iran. I have told her to give these out to our families who now live in the United States and in Australia. I have kept a few pieces for my grandchildren. This way my family can remember me.

Noor's narrative reveals that the fine pieces of embroidered work in homes do not merely constitute part of the décor. Containing motifs of flowers, animals, and abstract designs in different textures and colors, the handmade embroidery work of older women reflects life trajectories of families - transnational and otherwise. Noor's story is telling as it reveals the unfolding of larger events (village life, the market economy, revolution, and migration) occurring within the lifespan of a person. Each piece tells her story at different times and in particular contexts, depending on when and to whom it is given. There is another dimension that requires comment. She is 66 years old and lives with her son, his wife, and their three children. In our conversations, she relayed the point that she would not be able to go to Iran. "It is up to my son. He says, 'the fare is too high." Through her body language, disappointed look and downward gaze, it was evident that she believed her son could have afforded the fare. Noor took solace in the fact that her extended family here and there (host and home countries) would remember fragments of her life through the large number of embroidery pieces she had woven.

Noor's life story is woven into her embroidery work that she has kept for her kin so that she would be remembered. In subsequent meetings with her, I learned that she does not embroider any more - at least not after coming to Canada. She has the material and the threads but she has lost interest, stating that, "What I have embroidered contains our stories. People do not know our 
stories and the lives we have lived." Her putting closure to embroidery work gives the message that her life has come to an end. She observed, "We old people do not have much to live for. There is no interest in the past. The past is gone. The present is for the younger people. I am telling you that Canada is for younger people." The phrase "we old people" captures the situation of her cohort. There is power and dynamism in a collective narrative. When I inquired whether embroidery work of older women could make one feel at home in a palliative care situation, she said, "Yes. It would make us feel at home provided our stories are remembered." My conversations with older Iranians revealed that the issue of being remembered was very important. Study participants were well aware that the stories of their lives (here and there) were socially erased owing to "the busyness of our children's lives," summed up by the recurring phrase, "who has the time to listen." The participants hoped that at least at the time of death they would be remembered. And this remembrance takes place through storied vignettes evoked through embroidery work, a material and visible object that is not silent (Millar 2009).

Noor does not embroider as she thinks that there are no more stories to weave. In contrast, 64-year-old Rana conveyed the message that she has yet to live her life. Her story is not complete as symbolized in the incomplete piece of embroidery that she showed us while we were seated on the sofa in her living room. In one bag, she had embroidery needles and thread. Rana's narrative is as follows: She recalled that she lost her mother when she was only six years old. Her stepmother was unkind to Rana, made her work in the house, and "to get rid of me, she married me to an old man. I was only fifteen years old. I had two children with my first husband. He had two children as well. At a young age, I looked after four children and did all the housework." Her husband passed away. She was compelled to marry again so that she could have a home for herself and her children. "My second husband was abusive toward me like my first husband. He had three children of his own. My life continued as before. My eldest stepson moved to Canada. He called me for a visit. I stayed with him in Toronto. Things did not work out as he lost all the money he had brought with him. He moved to Vancouver but could not find work. He wanted me to go back to Iran. I refused. With the help of a friend, I claimed refugee status. Now I get some money from the government. But it is not enough. I live by myself in a small apartment."

When Rana came to Canada for a visit, she brought with her the unfinished embroidery work. She said that she would only work on it if she had a home where she did not have to worry about finances. Her response to our question on whether she thought that embroidery work would make a difference in a palliative care facility is as follows: "If I could, I would complete my embroidery work there. There would be rough threads in my embroidery. This is what life has been like for me. This would signify the end of my life." 
Rana's narrative reveals that embroidery work is a metaphor for reimagining a home. The embroidery artifact's concrete presence makes it "speak," signifying a lived life.

Let us imagine two pieces of embroidery before us, one is complete and the other is incomplete. The complete one has reached closure as Noor noted above: "I have nothing more to say and therefore I do not weave" (paraphrased). Rana, has not had a home in the deeper sense of the word, a place where she can feel financially secure and live a healthy and a happy life. Both women consider palliative care as a space where their embroidery work would capture in strands the stories of their lives in the home and host countries. Their reimagining of home - however incomplete - goes beyond how it is envisioned in palliative care. Here, feeling at home is expressed in terms of accommodating food preferences, and cultural and religious traditions to the extent possible and what makes one materially comfortable. The questions I raise are: how is it that immigrant older people, exemplified in the lives of the two women, seek acknowledgment of their lives at the time of death? What does this say about their reimagining a home in a new country? Is not the state implicated for according them the status of a dependent service population?

\section{Prayers: "Our home is where prayers are recited"}

A mutual friend introduced me to Gulbanu with the words, "You must go and see her. She is writing the story of her life for her grandchildren. She added, "her brother was in palliative care." Learning that I was doing research on aging and end-of-life within the Ismaili community, Gulbanu was more than happy to invite me to her condominium located in the vicinity of the Jamat Khana. Two things struck me when I entered her home: First was the large picture of her deceased husband right at the entrance. Donned in a lawyer's gown, his presence was felt. At the other end of the condominium were framed pictures of her four children and their families. Placed on the walls of the dining room, the pictures displaced her eight grandchildren. Second was the décor; the condominum was very well furnished with kitchen amenities. It was inviting and warm.

Gulbanu informed me that she lost her husband forty years ago from a massive heart attack. Sadly, he had just received the credentials to practice law in Canada. The couple left Tanzania with their children following the nationalization of Asian properties in the 1970s. They first went to England. "We had a very hard time. My husband could not practice law and we ended up doing the kind of work that we would not have imagined. We went back to Tanzania and realizing that our children had no future there, we applied to come to Canada. Our application was successful." Finding herself alone with her children, Gulbanu worked very hard. Initially she worked in a doctor's office and then in 
a clothing store. She worked in a bank for 17 years. All this while she took care of her children, ensured that had good educations, and maintained the house. She described her story as that of struggle. When I asked her how she managed, she responded, "It is through my faith. He (the divine being) is with me all the time." Throughout the course of relaying the story of her life, Gulbanu emphasized the point that it is her faith that has sustained her. She and her husband went to Jamat Khana every single day, in the mornings at 3:30 a.m. and in the evenings at 6:30 p.m. At one point, she observed, they lived 15 miles from Jamat Khana. "Even then we did not miss a single day." She has maintained this practice all her life. Presently, she lives close to Jamat Khana and resorts to it early in the morning (3:30 a.m.) and in the evening (6:30 p.m.).

Gulbanu's narrative is insightful. First, it reveals that reimagining of a home is not a discrete endeavor. It is relational. Her home is linked to the space in the Jamat Khana. She organized her everyday life around congregational prayer times. Furthermore, in the way of providing service, Gulbanu goes to Jamat Khana twice a week around mid-day to assist the council (an administrative body) with paperwork. She also takes cooked food to Jamat Khana as part of her contribution for ritual ceremonies. "All this work keeps me busy," she states. As she lives alone, her service work has assumed great importance. Gulbanu is in her late seventies. She is healthy. She observed that she exercises at home and is careful with her diet. She has a few friends with whom she goes out for lunch occasionally. Other than this, her social life revolves around her family, especially her daughter. Her well-furnished and well-decorated home suggest that she is nicely settled. Her home has meaning for her only because it is connected to Jamat Khana.

As I learnt more about Gulbanu's life, I realized how precarious it was. Her everyday routine informed by her connection to Jamat Khana would come to an end or would be diminished through age or ill health. She does not have a community per se. What she has built in the way of reimagining her home connected to Jamat Khana is solely through her efforts. When I asked her about the future, she was uncertain. Living with one of her children would render her dependent as she would be compelled to adopt their lifestyle. Gulbanu stated that if she had to live elsewhere (whether a nursing home or palliative care) her prayers and the "space" of the Jamat Khana that she had come to know as a child would be her solace. Though separated from the home she had reimagined in the diaspora, it would be an ensuring part of her life. It is this aspect that she sought to convey to her grandchildren. She stated, "Everything else will go. But the faith will remain forever." Her words evoked a scene that I was privy to several times:

Seventy-one-year old Khairoun lights incense and sits on the sofa in the family room at 7:00 a.m. every day without fail. She calls her family members with the words, "It is duia (prayer) time." She takes a rosary from a glass 
dish containing several that she has collected for the family. She waits for ten minutes for family members to join her if they so wish. Those who participate sit cross-legged on the floor. One person leads ten-minute du'a accompanied by rhythmic movements of the body in tune with the recitation of Quranic ayats (verses).

Realizing that her grandchildren may not participate at all times, she noted, "If not today then tomorrow (ajeh nahi toh kaleh) they will remember. Today's world is very bad (bahu kharab jamano che). Our children will need faith. Otherwise they will be lost. Mangoes do not ripen overnight. You have to give them time." It would not be an exaggeration to state that Gulbanu and her peers are engaged in the form of work that can be considered as existential. For them faith is linked to the issue of life and death. Gulbanu summed this up well, "Life has been a struggle. We survived through our faith. Now if we have to die, we would die in piece." Her usage of the word "we" suggest a testimonial insight of relevance to in her words, "whoever listens."

\section{Conclusion: Engaged Anthropology}

I began the paper with the question on the embedded paradox in palliative care. As an anthropologist, my starting point was to explore the views of the people who experience this paradox more intimately for which purpose I used the construct of emplacement. The construct's grounding in time and place made it possible to document aspects missed out in conventional approaches; in particular, the thematic frames as these came to light from the data revealed the importance of inclusive communities (mindful walking) and the need to acknowledge the narratives of study participants showing that palliative care should broaden its parameters (Shabina's memory work) and that it should revisit its premise of family-centered care (Rubina's memory work). The script at work is the restructuring of the Canadian health system that advocates selfcare and self-responsibility to absolve the state from its obligation to provide health to its citizens to which they are entitled. Reimagining home appeared as an important theme as the two immigrant communities (Iranians and Ismailis) sought to settle down in a new place. For this and the themes noted above, I chose a marginalized constituency of aging immigrants not solely for the reason that the state has rendered dependent but because they are the bearers of histories of their respective communities and they embody a repertoire of knowledge acquired over a lifetime, including crossing socio-cultural and politicized boundaries.

The study participants complicate our understanding of how immigrants (or migrant women) reimagine "home." While engaged in the cultural/legacy work, each participant presents a different scenario. Through the cultural ar- 
tifact of embroidery work, Noor and Rana relay their life histories showing that "home" for older immigrants is problematic. Noor has a home that the characteristic of which is defined by her son's family. Hence her comment, she does not engage into embroidery work as she has no more stories to share. Rana, on the other hand, is not able to reimagine a home owing to structural factors. In the way of a protest, she decides not to finish her embroidery work - an embodiment of life history. Gulbanu's reimagining of home materially and spiritually (Jamat Khana) does not free her from a precarious position. She is uncertain as to whether she would live with one of her children as a dependent or in a nursing home. Having lived independently, she does not desire any of these options; she takes solace in the fact that Jamat Khana (her other home) will always be with her along with the fact that she will leave a legacy of struggle as to how she was able to reimagine a home in her country of settlement. Study participants' (encapsulating the situation of their cohort) reimagining of home is markedly different from palliative care definition of home, which is in the words of a service provider, "To provide comfort and to accommodate the needs of the patients and their families."

My summation of the research findings suggests a disconnect between palliative care philosophy and practice, and the lived realities of the two immigrant communities, exemplified in singular narratives that represent a collective situation. There is much work to be done and it is towards this end that I foreground the potential of engaged anthropology to foster conversations across medicalized and politicized boundaries (Donahue 1998; Mykhalovskiy \& Mccoy 2002; Pink 2008; Thomas 1993). Committed to praxis and progressive change, engaged anthropology suggests multiple strategies entailing selfreflexivity and listening to the voices and stories of study participants for deeplevel conversations with stakeholders in this case, palliative care practitioners (Brondo 2010; Checker 2009; Clarke 2010; Low \& Merry, 2010; Susser 2010) to affect transformative change. Here, mindful walking, memory work, and reimagining home serve as genres encapsulating entangled emplacement, that is unfolding of structural factors in time and space, and how these shape the life trajectories of aging and older immigrants. This observation puts to rest the notion that diagnoses of terminal illness is not only one mode of medical activity. As Good has noted, if "diagnoses is viewed as the linking of a patient's condition to a disease category," (1977) then we will miss out on seeing pathology that exists in a patient's socio-political field. Engaged anthropologists have observed that illness, disease, dying, and death are deeply integrated into the fabric of society and increasing our inter-connected but unequal global world. It is toward this end that Good suggests that the meaning of medical language, including palliative care, must be understood as part of a semantic network. This network he suggests include words, experiences and feelings to which I would add genres such as "memory work" and "reimaging home" as they all 
come together for members of a diasporic communities-communities whose life worlds have been disrupted as I have illustrated in this paper.

\section{Limitations and Future Directions}

Research work is delimited as a matter of course. The delimitation is a function of the choice of field site and the people who choose to participate or not. In the case of palliative care, the limitations are greater as end-of-life is not the subject matter that people talk about openly. We live in a death-denying world. At the same time, the study of death (linked with life) can yield profound insights but also mask others. When it comes to racialized minorities, we need to recognize the latter's reluctance to critique the system. This is because they receive the message that they should be grateful for being in Canada with its international image of a tolerant and a peaceful country. Given this context, my study had two limitations. First, I could not engage the study participants to talk openly about end-of-life issues that mattered to them. Second, being mindful of the heterogeneity of the two communities under study, I have not been able to fully discuss the multiple and fluid locations that study participants occupy within Canada, including the diaspora.

Future directions can consider two scenarios: (a) create a culturally safe space for participants to discuss issues of life, dying and death in the contemporary world; (b) hold forums and workshops between racialized minorities (for whom palliative care can be alienation and inaccessible) and health practitioners with the understanding that the latter can gain knowledge from the diversity of populations comprising the Canadian mosaic.

\section{References}

Anderson, J. \& Kirkham, S. (1998). Constructing Nation: The Gendering and Racializing of the Canadian Health Care System. In V. Strong-Boag, S. Grave, A. Eisenberg \& J. Anderson (Eds.), Painting the maple: Essays on race, gender and the construction of Canada (pp. 242-261). Vancouver, B.C: University of British Columbia Press.

Brondo, K.V. (2010). Practising anthropology in a time of crisis: 2009 year in review. American Anthropologist, 112(2), 208-218. https://doi.org/10.1111/j.15481433.2010.01220.x

Checker, M. (2009). Anthropology in the public sphere, 2008: Emerging trends and significant impacts. American Anthropologist, 111(2), 162-169. https://doi. org/10.1111/j.1548-1433.2009.01109.x

Clarke, K. (2010). Toward a critically engaged ethnographic practice. Current Anthropology, 51(2), 301-312. https://doi.org/10.1086/653673

Dilworth-Anderson, P., Williams, I., \& Gibson, B. E. (2002). Issues of race, ethnicity 
and culture in caregiving research: A 20-year review (1980-2000). The Gerontologist, 42(2), 237-272. https://doi.org/10.1093/geront/42.2.237

Donahue, J. M. (1998). Critical Medical Anthropology. Medical Anthropology Quarterly, 12(2), 257-258. https://doi.org/10.1525/maq.1998.12.2.257

Dossa, P. (1985). Transmission and interpretation of the Ismaili Ritual (doctoral dissertation). University of British Columbia, Vancouver, Canada.

Dossa, P. (2004). Politics and poetics of migration: Narratives of Iranian women from the diaspora. Toronto: Canadian Scholar's Press.

Dossa, P. (2009). Racialized bodies, disabling worlds: Storied lives of immigrant Muslim women. Toronto: University of Toronto Press. https://doi. org/10.3138/9781442688919

Dyck, I. (2006). Travelling tales and migratory meanings: South Asian migrant women talk of place, health and healing. Social \& Cultural Geography, 7(1), 1-18. https:// doi.org/10.1080/14649360500452772

Erel, U. (2009). Migrant women transforming citizenship: Life stories from Britain and Germany. Abingdon, Oxon, GBR: Ashgate Publishing Group.

Erel, U. (2011). Reframing migrant mothers as citizens. Citizenship Studies, 15(6-7), 695-709. https://doi.org/10.1080/13621025.2011.600076

Frey, R., Gott, M., Raphael, L., Black, L., Teleo-Hope, L., Hyeonjoo, L., \& Zonghua, W. (2013). Where do I go from here? A cultural perspective on challenges to the use of hospice services. Health \& Social Care in the Community, 21(5), 519-529. https:// doi.org/10.1111/hsc. 12038

Gedalof, I. (2007). Unhomely homes: Women, family and belonging in UK discourses of migration and asylum. Journal of Ethnic and Migration Studies, 33(1). 77-94. https://doi.org/10.1080/13691830601043513

Gedalof, I. (2009). Birth, belonging and migrant Mothers: Narratives of reproduction in feminist migration studies. Feminist Review, 93(1), 81-100. doi:10.1057/ fr.2009.23. https://doi.org/10.1057/fr.2009.23

Gilmartin, M. \& Migge, B. (2015). Migrant mothers and the geographies of belonging. Gender, Place \& Culture, 23(2), 1-15.

Jung, Y. (2014). Mindful walking: The serendipitous journey of communitybased ethnography. Qualitative Inquiry, 20(5), 621-627. https://doi. org/10.1177/1077800413505543

Lamb, S. (2014). Permanent personhood or meaningful decline? Toward a critical anthropology of successful aging. Journal of Aging Studies, 29, 41-52. https://doi. org/10.1016/j.jaging.2013.12.006

Lock, M., \& Nguyen, V. (2010). An anthropology of biomedicine. Malden, Mass: WileyBlackwell.

Low, S., \& Merry, S. E. (2010). Engaged anthropology: Diversity and dilemmas: An introduction to supplement 2. Current Anthropology, 51(2), 203-226. https://doi. org/10.1086/653837

Low, S. (2011). Claiming space for an engaged anthropology: Spatial inequality and social exclusion. American Anthropologist, 113(3), 389-407. https://doi.org/10.1111/ j.1548-1433.2011.01349.x

Mankekar, P. (2002). 'India Shopping': Indian grocery stores and transnational configurations of belonging. Ethnos: Journal of Anthropology, 67(1), 75-97. https://doi. org/10.1080/00141840220122968

Miller, D. (2009). The Comfort of Things. Cambridge, London: Polity Press.

Mykhalovskiy, E. \& Mccoy, L. (2002). Troubling ruling discourses of health: Using 
institutional ethnography in community-based research. Critical Public Health, 12(1), 17-37. https://doi.org/10.1080/09581590110113286

Pink, S. (2008). An urban tour: The sensory sociality of ethnographic place-making Ethnography, 9(2), 175-196.

Rodman, M. (1992). Empowering place: Multilocality and multivocality. American Anthropologist, 94(3), 640-656. https://doi.org/10.1525/aa.1992.94.3.02a00060

Susser, I. (2010). The anthropologist as social critic: Working toward a more engaged anthropology. Current Anthropology, 51(2), 227-233. https://doi.org/10.1086/653127

Thomas, J. (1993). Doing Critical Ethnography. Northern Illinois University, USA: Sage. https://doi.org/10.4135/9781412983945

Williams, A. M., Crooks, V. A., Witfield, K., Kelley, M., Richards, J., Demiglio, L., \& Dykeman, S. (2010). Tracking the evolution of hospice palliative care in Canada: A comparative case study analysis of seven provinces. BMC Health Service Research, 10, 147-166. https://doi.org/10.1186/1472-6963-10-147

Witeska-Mlynarczyk, A. (2015). Critical medical anthropology: A voice for just and equitable healthcare. Annals of Agricultural and Environmental Medicine, 22(2), 385-389. https://doi.org/10.5604/12321966.1152099 